\title{
Uji Konsentrasi Hambat Minimum Ekstrak Daun Gedi (Abelmoschus manihot L. Medik) terhadap Pertumbuhan Streptococcus mutans
}

\author{
Benedicta N. D. Rori \\ Johanna A. Khoman \\ Aurelia S. R. Supit \\ Program Studi Pendidikan Dokter Gigi Fakultas Kedokteran \\ Universitas Sam Ratulangi Manado \\ Email: nathania.deandra10@gmail.com
}

\begin{abstract}
The main problem in dental health is dental caries that occurs due to the fermentation by Streptococcus mutans bacteria. Gedi leaf (Abelmoschus manihot L. Medical) is one of the common plants in Northern Celebes that contains antimicrobial compounds namely flavonoid, alkaloid, steroid, and saponin; all of them have been proved to inhibit the growth of S. mutans. This study was aimed to determine the minimal inhibitory concentration (MIC) of gedi leaf extract (Abelmoschus manihot L. Medical) to $S$. mutans growth. This was a true experimental study with a randomized pretest-posttest control group design. The method used in this study was serial dilution method with turbidimetry and spectrophotometry. Samples of gedi leaves were obtained at Paal 2 Manado, and were extracted with maceration method using ethanol 96\%. S. mutans bacteria were obtained from the pure bacterial stock at Microbiology Laboratory of Pharmacy Study Program, Faculty of Mathematics and Natural Science University of Sam Ratulangi Manado. The turbidimetry test showed that the tube content became clearer at $25 \%$ of extract concentration. Moreover, the UV-Vis spectrophotometer showed a decrease of $\triangle \mathrm{OD}$ value for the first time at $25 \%$ of extract concentration. Conclusion: The minimal inhibitory concentration (MIC) of gedi leaf extract (Abelmoschus manihot L. Medical) to Streptococcus mutans growth was at concentration of $25 \%$.
\end{abstract}

Keywords: gedi leaf (Abelmoschus manihot L. Medical), Streptococcus mutans, MIC, dental caries

\begin{abstract}
Abstrak: Masalah utama dalam kesehatan gigi ialah karies gigi yang terbentuk karena proses peragian oleh bakteri Streptococcus mutans. Daun gedi (Abelmoschus manihot L. Medik) merupakan salah satu tanaman khas daerah Sulawesi Utara yang mengandung senyawa antimikroba berupa flavonoid, alkaloid, steroid, dan saponin yang telah terbukti memiliki efek antibakteri terhadap pertumbuhan $S$. mutans. Penelitian ini bertujuan untuk mengetahui konsentrasi hambat minimum (KHM) ekstrak daun gedi (Abelmoschus manihot L. Medik) terhadap pertumbuhan S. mutans. Jenis penelitian ialah eksperimental murni dengan pretestposttest control group design. Metode yang digunakan dalam penelitian ini yaitu metode serial dilusi dengan pengujian turbidimetri dan spektrofotometri. Daun gedi diperoleh dari Kecamatan Paal 2 Manado, dan diekstraksi dengan metode maserasi menggunakan pelarut etanol 96\%. Bakteri S. mutans diambil dari stok bakteri murni Laboratorium Mikrobiologi Program Studi Farmasi Fakultas MIPA Universitas Sam Ratulangi Manado. Hasil pengujian turbidimetri memperlihatkan bahwa larutan dalam tabung terlihat mulai jernih pada konsentrasi ekstrak 25\%. Pada pengujian spektrofotometer UV-Vis terlihat penurunan nilai $\triangle$ OD pertama kali pada konsentrasi $25 \%$. Simpulan: Konsentrasi hambat minimum ekstrak daun gedi (Abelmoschus manihot L. Medik) terhadap pertumbuhan Streptococcus mutans terdapat pada konsentrasi $25 \%$.
\end{abstract}

Kata kunci: daun gedi (Abelmoschus manihot L. Medik), Streptococcus mutans, KHM, karies 
Kesehatan gigi dan mulut sudah menjadi prioritas yang utama bagi masyarakat saat ini. Gigi dan mulut merupakan pintu gerbang masuknya kuman dan bakteri yang dapat mengganggu kesehatan organ tubuh lainnya. Menurut data Riskesdas tahun 2013, prevalensi nasional masalah gigi dan mulut ialah sebesar 25,9\% dan sebanyak 14 provinsi mempunyai prevalensi masalah gigi dan mulut di atas angka nasional. Masalah utama dalam kesehatan gigi ialah karies gigi yang diderita oleh hampir semua penduduk di Indonesia. ${ }^{1}$

Karies gigi terbentuk karena proses peragian oleh bakteri Streptococcus mutans (S. mutans) yang merupakan salah satu mikroflora normal dalam rongga mulut. Meskipun merupakan flora normal, dalam keadaan tertentu bakteri tersebut bisa menjadi patogen karena adanya faktor predisposisi. Sisa-sisa makanan yang terdapat pada rongga mulut akan diuraikan oleh bakteri ini menjadi asam. Asam yang terbentuk kemudian menempel pada email dan dapat menyebabkan demineralisasi. Jika demineralisasi berlangsung secara terus menerus, maka terjadi karies gigi. ${ }^{2}$

Berbagai upaya pencegahan karies gigi dilakukan baik secara mekanis maupun kimiawi; diantaranya ialah pengaturan diet, kontrol plak, penggunaan fluor, kontrol bakteri kariogenik, penggunaan obat kumur, dan fissure sealant. Pencegahan dengan cara kimiawi sering menggunakan bahan sintetis yang memiliki efek samping kurang baik. Oleh karena itu, penggunaan tanaman herbal saat ini telah dikembangkan di bidang kedokteran maupun kedokteran gigi. ${ }^{3}$

Salah satu tumbuhan yang mudah ditemukan di daerah Sulawesi Utara yaitu edi (Abelmoschus manihot L. Medik). Daun gedi merupakan salah satu tanaman khas daerah Sulawesi Utara yang biasa dikonsumsi sebagai sayuran. Daun gedi merupakan salah satu tumbuhan dari famili Malvaceae. Penggunaan daun gedi sebagai obat tradisional telah banyak dikenal oleh masyarakat di Minahasa. Daun gedi dimanfaatkan sebagai penanganan herbal yang dapat menyembuhkan beberapa penyakit seperti diabetes, kolesterol dan hipertensi. ${ }^{4}$
Penelitian yang dilakukan oleh Mandey et al. ${ }^{5}$ serta Sangi et al. ${ }^{6}$ membuktikan bahwa daun gedi mengandung senyawa flavonoid, alkaloid, steroid, dan saponin yang memiliki efek sebagai antimikroba dengan mekanisme kerja yang berbedabeda. Penelitian lebih lanjut dilakukan oleh Mokoginta et al. ${ }^{7}$ membuktikan bahwa ekstrak daun gedi pada konsentrasi $100 \%$ memiliki efek antibakteri terhadap bakteri $S$. mutans. Namun, dari penelitian-penelitian tersebut belum diketahui nilai konsentrasi hambat minimumnya. ${ }^{7}$

\section{BAHAN DAN METODE PENELITIAN}

Jenis penelitian ini ialah eksperimental murni dengan randomized pretest-posttest control group design. Penelitian dilakukan di Laboratorium Mikrobiologi Program Studi Farmasi Fakultas MIPA Universitas Sam Ratulangi pada bulan Maret-April 2018. Subjek penelitian ialah bakteri biakan murni Streptococcus mutans dari rongga mulut yang diperoleh di Laboratorium Mikrobiologi Program Studi Farmasi Fakultas MIPA Universitas Sam Ratulangi Manado. Metode penelitian yang digunakan ialah metode serial dilusi atau pengenceran bertingkat dengan perbandingan 1:2 $(\mathrm{w} / \mathrm{v})$. Metode pengujian yang dipakai dalam penelitian ini ialah metode turbidmetri dan metode spektrofotometri.

Sebanyak $2 \mathrm{~kg}$ daun gedi dicuci bersih dibawah air mengalir, ditiriskan, dipotongpotong, dan dikeringkan pada suhu ruangan selama 5 hari, kemudian di maserasi sebanyak $2 x$ pengulangan. Maserasi I menggunakan $1500 \mathrm{ml}$ aquades dan maserasi II menggunakan $750 \mathrm{ml}$ aquades. Hasil proses maserasi I dan II yang telah disaring menggunakan kertas Whattman no. 42, diuapkan dengan rotary vacuum evaporator dan oven pada suhu $40^{\circ} \mathrm{C}$ untuk mendapatkan ekstrak gedi $100 \%$.

Pembuatan media stok kultur bakteri menggunakan nutrient agar (NA). Pembuatan media suspensi bakteri menggunakan nutrient broth (NB). Selain itu digunakan juga larutan $\mathrm{BaCl}_{2} \quad 1,175 \%$ dan larutan $\mathrm{H}_{2} \mathrm{SO}_{4} 1 \%$ sebagai larutan baku McFarland 1. Nilai absorban larutan baku McFarland 1 
setara jumlah sel bakteri dengan kepadatan $0,3 \times 10^{9}$ bakteri $/ \mathrm{ml}$.

Satu koloni bakteri $S$. mutans diambil dengan menggunakan jarum ose steril, ditanamkan pada media NA miring dengan cara menggores, kemudian diinkubasi dalam inkubator pada suhu $37^{\circ} \mathrm{C}$ selama $1 \times 24$ jam. Stok kultur bakteri S. mutans yang telah tumbuh diambil dengan jarum ose steril lalu disuspensikan dalam tabung reaksi yang berisi $10 \mathrm{ml}$ larutan $\mathrm{NaCl} 0,9 \%$ sampai didapat kekeruhan suspensi bakteri sama dengan kekeruhan larutan standard McFarland 1. Setelah itu dilakukan pengenceran dengan memipet $0,1 \mathrm{ml}$ suspensi bakteri, dimasukkan ke dalam tabung steril dan ditambahkan larutan $\mathrm{NaCl} 0,9 \%$ sebanyak 9,9 ml dan dikocok hingga homogen.

Sebanyak 6 tabung reaksi steril disiapkan. Tabung uji 1-4 diberi label 100\%, $50 \%$, 25\%, dan $12,5 \%$. Pada tabung 5 diberi label $\mathrm{K}(+)$ yang merupakan kontrol positif, yaitu tabung yang berisi larutan standar Mc Farland 1. Pada tabung 6 diberi label $\mathrm{K}(-)$ yang merupakan kontrol negatif, yaitu tabung berisi media NB.

Sebanyak $4 \mathrm{ml}$ media NB steril dimasukkan ke dalam masing-masing tabung reaksi $1-4$, kemudian ditambahkan $0,5 \mathrm{ml}$ ekstrak dengan masing-masing ekstrak dibuat 4 konsentrasi $100 \%, 50 \%, 25 \%$, dan $12,5 \%(100 \mathrm{mg} / \mathrm{ml}, 50 \mathrm{mg} / \mathrm{ml}, 25 \mathrm{mg} / \mathrm{ml}$, dan $12,5 \mathrm{mg} / \mathrm{ml})$. Selanjutnya ke dalam tabung reaksi 1-4 ditambahkan $0,5 \mathrm{ml}$ suspensi bakteri $S$. mutans yang sudah disesuaikan dengan larutan standard kekeruhan McFarland 1. Pada tabung 5 dimasukkan $5 \mathrm{ml}$ larutan McFarland 1, sedangkan pada tabung 6 dimasukkan $5 \mathrm{ml}$ media NB. Tabung-tabung reaksi tersebut kemudian diukur nilai optical density (OD) dengan menggunakan spektrofotometer, lalu diinkubasi ke dalam inkubator selama $1 \times 24$ jam pada suhu $37^{\circ} \mathrm{C}$. Pada penelitian ini, perlakuan dan pengujian diulang sebanyak tiga kali.

Pengujian dengan menggunakan metode turbidimetri dilakukan setelah media tabung perlakuan diinkubasi selama $1 \times 24$ jam. Semua tabung tersebut dilihat kekeruhannya secara visual. Apabila kekeruhan masing-masing tabung masih setara atau lebih keruh dari tabung $\mathrm{K}(+)$ yang berisi larutan standar McFarland 1, berarti bakteri masih dapat bertumbuh tetapi bila larutan dalam tabung terlihat mulai lebih jernih daripada tabung $\mathrm{K}(+)$ atau mendekati kejernihan tabung $\mathrm{K}(-)$ yang berisi media NB, berarti pertumbuhan bakteri sudah mulai terhambat; hal ini yang menunjukkan konsentrasi hambat minimum (KHM).

Setelah media tabung perlakuan diinkubasi selama 1x24 jam, semua tabung perlakuan diukur lagi nilai OD-nya dengan spektrofotometer untuk melihat selisih nilai OD $(\Delta \mathrm{OD})$. Jika nilai $\Delta \mathrm{OD}$ (nilai OD setelah inkubasi $1 \times 24$ jam dikurangi nilai OD sebelum inkubasi 1x24 jam) positif, maka disimpulkan bahwa masih terjadi pertumbuhan bakteri namun jika nilai $\Delta \mathrm{OD}$ negatif, maka disimpulkan bahwa partumbuhan bakteri telah dihambat. Konsentrasi hambat minimum ditentukan dengan melihat konsentrasi ekstrak terkecil pada tabung perlakuan dengan nilai $\Delta \mathrm{OD} \leq 0$.

\section{HASIL PENELITIAN}

Penelitian ini dilakukan di Laboratorium Mikrobiologi Program Studi Farmasi Fakultas MIPA Universitas Sam Ratulangi yang bertujuan untuk mendapatkan data tentang KHM ekstrak daun gedi terhadap pertumbuhan $S$. mutans, yang diuji dengan menggunakan metode turbidimetri dan metode spektrofotometri.

Pengujian menggunakan metode turbidimetri dilakukan dengan tiga kali perlakuan. Hasil pengujian turbidimetri pada perlakuan ke-1 (Gambar 1), ke-2 (Gambar 2), dan ke-3 (Gambar 3) menunjukkan KHM ekstrak daun gedi terhadap pertumbuhan $S$. mutans yaitu pada konsentrasi $25 \%$, dimana pada konsentrasi $25 \%$ tabung sudah terlihat mulai jernih. Larutan pada tabung menjadi semakin jernih pada konsentrasi $50 \%$ dan $100 \%$, tetapi terlihat semakin keruh pada konsentrasi 12,5\% (Tabel 1).

Pengujian dilanjutkan dengan pengukuran nilai OD menggunakan spektrofotometer UV-Vis. Pengukuran nilai OD dilakukan pada tabung 1-6 sebanyak tiga kali perlakuan, sebelum dan setelah inku- 
basi $1 \times 24$ jam untuk melihat nilai $\Delta \mathrm{OD}$. Dari hasil pengujian spektrofotometer UVVis terlihat penurunan nilai $\Delta \mathrm{OD}$ pertama kali pada konsentrasi 25\% (Tabel 2). Oleh karena itu konsentrasi $25 \%$ ditentukan sebagai KHM ekstrak daun gedi terhadap pertumbuhan $S$. mutans.

\section{BAHASAN}

Pada penelitian ini dilakukan uji KHM ekstrak daun gedi (Abelmoschus manihot L. Medik) terhadap pertumbuhan $S$. mutans dengan menggunakan pengenceran bertingkat perbandingan 1:2 (w/v) yaitu $100 \%$, $50 \%, 25 \%$, dan $12,5 \%$. Terdapat dua cara pengujian, yaitu: uji turbidimetri untuk melihat nilai kekeruhan secara visual dan pengukuran nilai OD menggunakan spektrofotometer UV-Vis. Pada penelitian ini tabung yang akan diuji diinkubasi pada suhu $37^{\circ} \mathrm{C}$ selama $1 \times 24$ jam, guna memaksimalkan pertumbuhan bakteri dengan cara menyamakan dengan habitat aslinya yaitu dalam tubuh manusia. ${ }^{8}$ Pengujian dengan metode turbidimetri dilakukan setelah diinkubasi selama 24 jam sedangkan pengujian menggunakan spektrofotometer UV-Vis dilakukan sebelum dan setelah inkubasi selama 24 jam.

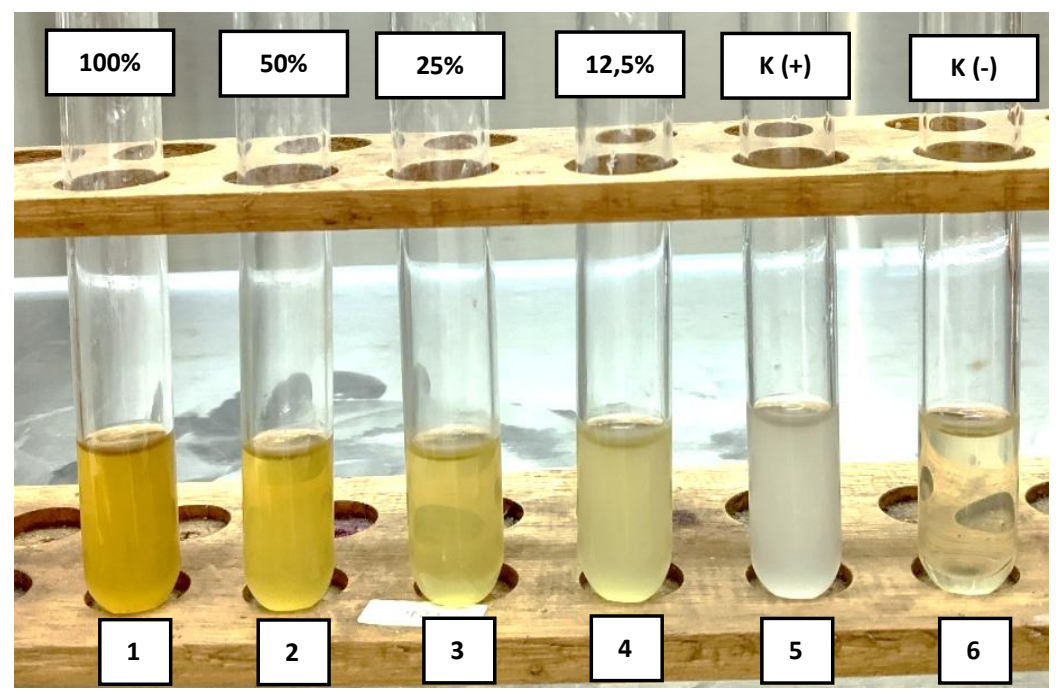

Gambar 1. Perlakuan pertama, uji KHM ekstrak daun gedi (Abelmoschus manihot L. Medik) terhadap pertumbuhan Streptococcus mutans dengan metode turbidimetri

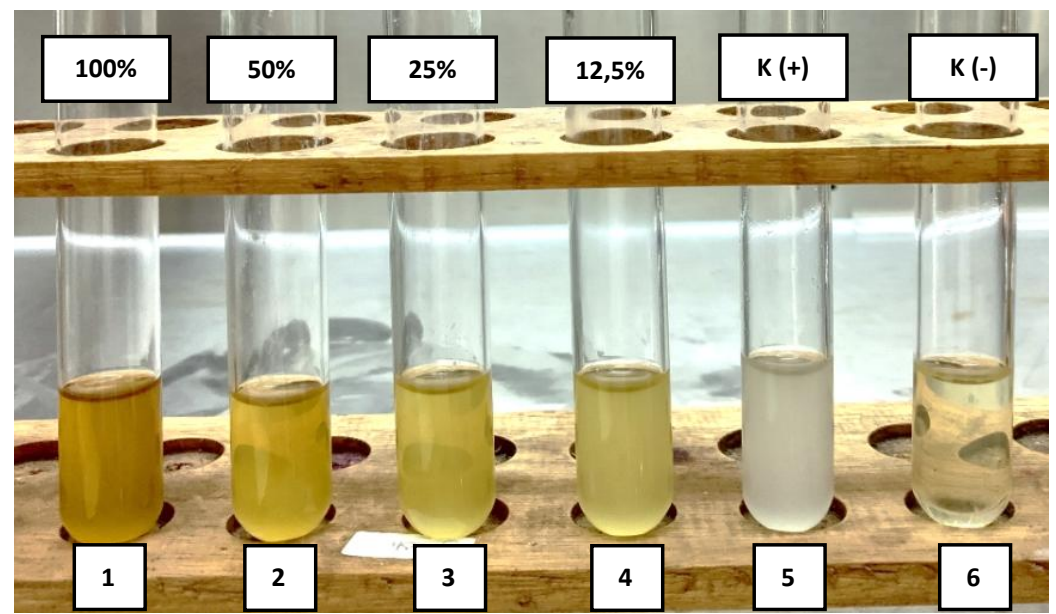

Gambar 2. Perlakuan kedua, uji KHM ekstrak daun gedi (Abelmoschus manihot L. Medik) terhadap pertumbuhan Streptococcus mutansdengan metode turbidimetri 


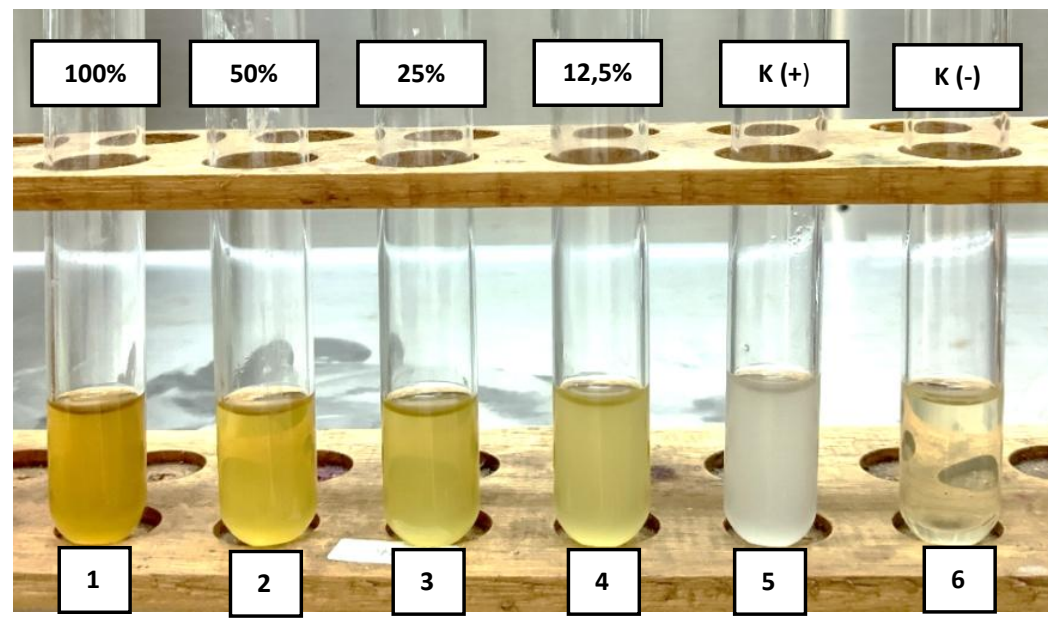

Gambar 3. Perlakuan ketiga, uji KHM ekstrak daun gedi (Abelmoschus manihot L. Medik) terhadap pertumbuhan Streptococcus mutans dengan metode turbidimetri

Tabel 1. Hasil uji KHM ekstrak daun gedi (Abelmoschus manihot L. Medik) terhadap pertumbuhan Streptococcus mutans pada perlakuan pertama, kedua dan ketiga dengan metode turbidimetri

\begin{tabular}{ccccc}
\hline \multirow{2}{*}{$\begin{array}{c}\text { Nomor } \\
\text { Tabung }\end{array}$} & $\begin{array}{c}\text { Konsentrasi ekstrak } \\
\text { daun gedi }\end{array}$ & $\begin{array}{c}\text { Perlakuan } \\
\text { ke-1 }\end{array}$ & $\begin{array}{c}\text { Perlakuan } \\
\text { ke-2 }\end{array}$ & $\begin{array}{c}\text { Perlakuan } \\
\text { ke-3 }\end{array}$ \\
\hline 1 & $100 \%$ & - & - & - \\
2 & $50 \%$ & - & - & - \\
3 & $25 \%$ & - & - & - \\
4 & $12,5 \%$ & + & + & + \\
5 & $\mathrm{~K}(+)$ & + & + & + \\
6 & $\mathrm{~K}(-)$ & - & - & - \\
\hline
\end{tabular}

Keterangan : Tanda (+) menunjukkan larutan di dalam tabung terlihat keruh yang berarti bahwa bakteri Streptococcus mutans masih dapat bertumbuh; sedangkan tanda (-) menunjukkan larutan di dalam tabung terlihat jernih yang berarti bahwa pertumbuhan bakteri Streptococcus mutans mulai terhambat.

Tabel 2. Hasil uji KHM ekstrak daun gedi (Abelmoschus manihot L. Medik) terhadap pertumbuhan Streptococcus mutans pada perlakuan pertama, kedua dan ketiga dengan menggunakan spektrofotometerUV-Vis

\begin{tabular}{|c|c|c|c|c|c|c|c|c|}
\hline \multirow{3}{*}{$\begin{array}{l}\text { Nomor } \\
\text { tabung }\end{array}$} & \multirow{3}{*}{$\begin{array}{c}\text { Konsentrasi } \\
\text { ekstrak daun } \\
\text { gedi }\end{array}$} & \multicolumn{6}{|c|}{ Nilai Optical Density (OD) } & \multirow{3}{*}{$\Delta \mathrm{OD}$} \\
\hline & & \multicolumn{2}{|c|}{ Perlakuan I } & \multicolumn{2}{|c|}{ Perlakuan II } & \multicolumn{2}{|c|}{ Perlakuan III } & \\
\hline & & $\begin{array}{l}\text { Sebelum } \\
\text { inkubasi }\end{array}$ & $\begin{array}{l}\text { Setelah } \\
\text { inkubasi }\end{array}$ & $\begin{array}{l}\text { Sebelum } \\
\text { inkubasi }\end{array}$ & $\begin{array}{c}\text { Setelah } \\
\text { inkubasi }\end{array}$ & $\begin{array}{l}\text { Sebelum } \\
\text { inkubasi }\end{array}$ & $\begin{array}{c}\text { Setelah } \\
\text { inkubasi }\end{array}$ & \\
\hline 1 & $100 \%$ & 0,340 & 0,568 & 0,352 & 0,549 & 0,354 & 0,448 & 0,173 \\
\hline 2 & $50 \%$ & 0,276 & 0,210 & 0,223 & 0,210 & 0,230 & 0,209 & $-0,033$ \\
\hline 3 & $25 \%$ & 0,263 & $\mathbf{0 , 1 7 7}$ & 0,290 & 0,182 & $\mathbf{0 , 3 0 2}$ & $\mathbf{0 , 1 7 8}$ & $-0,106$ \\
\hline 4 & $12,5 \%$ & 0,156 & 0,232 & 0,154 & 0,245 & 0,154 & 0,260 & 0,091 \\
\hline 5 & $\mathrm{~K}(+)$ & 0,783 & 0,767 & 0,692 & 0,759 & 0,769 & 0,765 & 0,015 \\
\hline 6 & $\mathrm{~K}(-)$ & 0,066 & 0,055 & 0,069 & 0,059 & 0,061 & 0,059 & $-0,008$ \\
\hline
\end{tabular}


Melalui uji turbidimetri dengan penglihatan secara kasat mata sebanyak 3 kali perlakuan, didapatkan KHM ekstrak daun gedi terhadap pertumbuhan $S$. mutans pada konsentrasi $25 \%$ karena pada tabung dengan konsentrasi $25 \%$ sudah mulai terlihat perubahan turbiditasnya (isi tabung mulai jernih) yang berarti tidak ada pertumbuhan bakteri dan dapat dikatakan sebagai KHM. ${ }^{9}$ Nilai KHM ditentukan berdasarkan konsentrasi terendah yang mampu melakukan penghambatan. ${ }^{10}$ Hasil pengamatan KHM melalui metode turbidmetri (pengamatan secara visual) pada penelitian ini sebenarnya sudah cukup untuk menentukan KHM, tetapi metode ini bersifat kualitatif dan dapat dipengaruhi oleh warna larutan yang bisa mencapai warna kecoklatan (pekat). ${ }^{8}$ Selain itu, metode turbidimetri juga memiliki kelemahan yaitu ketidakmampuan mata manusia untuk membedakan antara sel bakteri hidup dengan sel bakteri mati pada saat pengamatan kekeruhan yang dapat menghasilkan hasil yang kurang akurat. ${ }^{11}$ Oleh karena itu, untuk mendapatkan hasil yang akurat perlu dilakukan pengujian lebih lanjut dengan mengukur nilai OD menggunakan spektrofotometer UV-Vis.

Penentuan KHM melalui metode spektrofotometri dilakukan dengan membandingkan selisih OD sebelum dan sesudah inkubasi. Jika nilai OD $\leq 0$ maka didapatkan nilai KHM. ${ }^{12}$ Nilai $\Delta \mathrm{OD}$ yang negatif (-) menunjukkan adanya penurunan nilai absorbansi yang berarti terjadi penurunan jumlah bakteri setelah inkubasi 24 jam, sedangkan nilai $\Delta$ OD yang positif $(+)$ menunjukkan tidak adanya penurunan melainkan terjadi peningkatan nilai absorbansi yang berarti masih terjadi peningkatan jumlah sel bakteri setelah inkubasi 24 jam. ${ }^{13}$ Penurunan nilai $\Delta \mathrm{OD}$ pertama kali terjadi pada tabung dengan konsentrasi $25 \%$ sehingga konsentrasi $25 \%$ ditetapkan sebagai KHM ekstrak daun gedi terhadap pertumbuhan $S$. mutans.

Melalui hasil penelitian terdapat perbedaan hasil uji pada konsentrasi $100 \%$ yang dianalisis menggunakan metode turbidimetri dan spektrofotometer UV-Vis. Peningkatan nilai $\Delta \mathrm{OD}$ pada konsentrasi $100 \%$ dengan uji spektrofotometri UV-Vis setelah inkubasi 1x24 jam dapat disebabkan oleh karena partikel lain dalam larutan berupa sisa ekstrak (residu) yang tidak homogen bersama larutan dapat menyerap cahaya. Juga dapat dipengaruhi oleh penyerapan cahaya oleh larutan dalam tabung yang tidak sepenuhnya diserap oleh senyawa ekstrak, tetapi juga ikut terserap oleh sel bakteri yang telah mati. ${ }^{14}$ Selain itu dapat juga diakibatkan karena faktor kelemahan spektrofotometri UV-Vis dalam selektivitas untuk membedakan sampel dengan partikel-partikel lain atau kontaminan yang menyerap cahaya dalam panjang gelombang yang sama. ${ }^{15-17}$

Untuk mendapatkan hasil yang lebih akurat dibutuhkan pengujian dengan metode Kromatografi Cair Kinerja Tinggi (KCKT). Alat KCKT ialah suatu teknik kromatografi dengan fasa gerak cairan dan fasa diam cairan atau padat yang mempunyai banyak kelebihan dibandingkan metode lainnya. ${ }^{18}$ Dengan penggunaan metode KCKT, dapat dihasilkan data yang lebih rinci karena dalam instrumen KCKT terjadi pemisahan tiap-tiap komponen sehingga dapat diketahui kandungan dari sampel hasil ekstraksi. Hasil analisis KCKT ini merupakan analisis senyawa murni. ${ }^{19}$ Penelitian yang dilakukan di India oleh Joshi et al. ${ }^{20}$ yang membandingkan hasil metode spektrofotometri dengan metode KCKT melaporkan bahwa metode KCKT memiliki hasil yang lebih baik dari pada metode spektrofotometri dari segi ketelitian, sensitivitas, serta keakuratan dalam membaca nilai absorbansi.

Uji KHM ekstrak daun gedi terhadap pertumbuhan bakteri $S$. mutans dengan 3 kali perlakuan belum pernah dilakukan sebelumnya. Berdasarkan penelitian ini, KHM ekstrak daun gedi (Abelmoschus manihot L. Medik) terhadap pertumbuhan bakteri Streptococcus mutans yaitu pada konsentrasi $25 \%$ yang diperoleh melalui hasil pengukuran dengan metode turbidimetri serta metode spektrofotometri. 


\section{SIMPULAN}

Berdasarkan hasil penelitian ini dapat disimpulkan bahwa konsentrasi hambat minimum (KHM) ekstrak daun gedi (Abelmoschus manihot L. Medik) terhadap pertumbuhan Streptococcus mutans terdapat pada konsentrasi $25 \%$.

\section{SARAN}

Disarankan untuk melakukan uji konsentrasi bunuh minimum (KBM) ekstrak daun gedi (Abelmoschus manihot L. Medik) terhadap pertumbuhan Streptococcus mutans. Dapat dilakukan penelitian lebih mendalam mengenai kandungan zatzat aktif pada ekstrak daun gedi (Abelmoschus manihot L. Medik) yang dapat memengaruhi pertumbuhan Streptococcus mutans. Dapat dilakukan penelitian mengenai uji konsentrasi hambat minimum (KHM) ekstrak daun gedi (Abelmoschus manihot L. Medik) terhadap pertumbuhan Streptococcus mutans dengan menggunakan metode Kromatografi Cair Kinerja Tinggi (KCKT) untuk memperoleh hasil yang lebih akurat.

\section{DAFTAR PUSTAKA}

1. Badan Penelitian dan Pengembangan Kesehatan. Riset kesehatan dasar riskesdas 2013. Jakarta: Kementrian Kesehatan RI; 2013.h. 147 - 54.

2. Imaculata R, Tedjosasongko $\mathbf{U}$, Cornelia $\mathbf{S}$. Pemberian minyak wijen (Sesamum indicum, L) terhadap Streptococcus mutans (in vitro). Indonesian Pediatric Dental Journal. 2010;2(3):2.

3. Tarigan R. Karies Gigi (2nd ed). Jakarta: EGC, 2013; p. 1, 75-7.

4. Suoth E, Kaempe H, Tampi A. Evaluasi kandungan total polifenol danisolasi senyawa flavonoid pada daun gedi merah (Abelmoschus manihot L.). Chemistry Progress Majalah Publikasi Ilmu Kimia. 2013;6(2):86-9.

5. Mandey JS, Soetanto H, Sjofjan O, Tulung B. Genetic characterization, nutritional and phytochemical potential of gedi leaves (Abelmoschus manihot L. Medik) growing in the North Sulawesi of Indonesia as a candidate of poultry feed. Journal of Research in Biology. 2014;4(2):1276-86.
6. Sangi M, Runtuwene Max RJ, Simbala Henry EI, Makang Veronica MA. Analisis fitokimia tumbuhan obat di Kabupaten Minahasa Utara. Chemistry progress. 2008;1(1):49.

7. Mokoginta AS, Abidjulu J, Leman MA. Uji daya hambat sediaan ekstrak daun gedi (Abelmoschus manihot L.) terhadap pertumbuhan Streptococcus mutans. [Skripsi]. Manado: Universitas Sam Ratulangi; 2016.

8. Astutiningsih $\mathbf{C}$, Setyani $\mathbf{W}$, Hindratna $\mathbf{H}$. Uji daya antibakteri dan identifikasi isolat senyawa katekin dari daun teh (Camellia sinensis L. var Assamica). Jurnal Farmasi Sains dan Komunitas. 2014;11(2):50-7.

9. Munfaati PN, Ratnasari E, Trimulyono G. Aktivitas senyawa antibakteri ekstrak herba meniran (Phyllanthus niruri) terhadap pertumbuhan bakteri Shigella dysenteriae secara in vitro. Lentera Bio. 2015;4(1):64-71.

10. Maisak H, Tipmongkolsilp N, Wongtavatchai J. Minimum inhibitory concentrations of antimicrobials against clinical vibrio and streptococcus isolated from aquaculture. Diseases in Asian Aquaculture. 2011;VII:309-16.

11. Pajan SA, Waworuntu O, Leman MA. Potensi antibakteri air perasan bawang putih (Allium Sativum L) terhadap pertumbuhan Staphylococcus aureus. eG. 2016;5(4):77-89.

12. Yunika N, Irdawati, Fifendy M. Konsentrasi hambat minimum ekstrak daun sawo (Achras Zapota L.) terhadap pertumbuhan Staphylococcus Aureus secara in vitro. Bioscience. 2017;1(1): 53-9.

13. Maftuhah A, Bintari SH, Mustikaningtyas D. Pengaruh infusa daun beluntas (Pluchea Indica) terhadap pertumbuhan bakteri Staphylococcus epidermidis. Unnes Journal of Life Science. 2015; 4(1):62.

14. Dewi FK. Aktivitas antibakteri ekstrak etanol buah mengkudu (Morinda citrifolia, Linnaeus) terhadap bakteri pembusuk daging segar [Skripsi]. Surakarta: Universitas Sebelas Maret: 2010.

15. Geisler J, Thompson T. Choosing the best detection method: absorbance vs. fluorescence. [internet]. [cited $11 \mathrm{Mei}$ 2018]. Available from: www. 
biocompare.com/BenchTips/17396Choosing-the-Best-Detection-MethodAbsorbance-vs-Fluorescence.

16. Watson DG. Pharmaceutical Analysis (2nd ed). London: Elsevier, 2005; p. 88.

17. Septian K. Uji konsentrasi hambat minimum (KHM) ekstrak spons laut Callyspongia sp. terhadap pertumbuhan Staphylococcus aureus. Dentire. 2016;5(1): 510.

18. Joshi HR, Patel AH, Captain AD. Spectrophotometric and reversed-phase highperformance liquid chromato-graphic method for the determination of doxophylline in pharmaceutical formulations. J Young Pharm. 2010;2(3):
295.

19. Annisa S, Surjani W, Nena Z. Perbandingan metode spektrofotometri UVVis dan KCKT (Kromotografi Cair Kinerja Tinggi) pada analisis kadar asam benzoat kafein dalam teh kemasan. Malang; Universitas Negeri Malang; 2011.

20. Joshi HR, Patel AH, Captain AD. Spectrophotometric and reversed-phase highperformance liquid chromate-graphic method for determination of doxophylline in pharmaceutical formulations. J Young Pharm. 2010; 2(3):28996. 